CARADDE: Jurnal Pengabdian Kepada Masyarakat
$\begin{gathered}\text { https://journal.ilininstitute.com/index.php/caradde } \\ \text { Volume 2 | Nomor 2 | Februari | 2020 } \\ \text { e-ISSN: } 2621-7910 \text { dan p-ISSN: 2621-7961 }\end{gathered}$
DOI: https://doi.org/10.31960/caradde.v2i2.372

\title{
PKM Penyelenggaraan Pemerintahan Dalam Perencanaan Pembangunan Negeri Hila Kabupaten Maluku Tengah
}

\section{Marno Wance ${ }^{1}$ Muhtar $^{2}$ Pahrul Idham Kaliky ${ }^{3}$}

\author{
Keywords : \\ Pemerintahan Negeri; \\ Pembangunan Desa; \\ Tata Kelola Keuangan.

\section{Corespondensi Author} \\ ${ }^{12}$ Ilmu Pemerintahan, \\ ${ }^{3}$ Ilmu Komunikasi, Universitas \\ Pattimura. \\ Jln. Ir M. Putuhena, \\ Poka, Kota Ambon \\ Email: \\ marno.wance@fisip.unpatti.ac.id
}

\section{History Article}

Received: 18-Januari-2020;

Reviewed: 14-Januari-2020;

Accepted: 02-Februari-2020;

Avalaible Online: 02-Februari-2020;

Published: 14-Februari-2020

\begin{abstract}
Abstrak. Tujuan Pengabdian Kepada Masyarakat ini untuk memberikan pemahaman bagi masyarakat dan pemerintahan negeri Hila dalam berkolaborasi pada perencanaan pembangunan di desa. Pelatihan serta FGD dilakukan oleh Akademisi FISIP Universitas Pattimura bertujuan untuk meningkatkan kapasitas pemerintah negeri Hila dalam penyelenggaran pemerintah yang baik berdasarkan prinsip tata kelola keuangan desa dan perencanaan pembangunan desa. Metode yang dilaksanakan dua tahapan yaitu persipanan dan pelaksanaan.PKM Menggunakan pendekatan penelitian yaitu Metode pelatihan dan FGD di Kantor Desa bersama pemerintah negeri Hila dan Mahasiswa. Sumber data primer yaitu dengan melakukan wawancara secara langsung dengan pemerintah Negeri Hila dan perangkat Negeri. Simpulan pada PKM di Negeri Hila yaitu tata kelola penyelenggaran pemerintahan Negeri Hila dan lembaga saniri dalam merencanakan pembangunan di Desa Hila.
\end{abstract}

\begin{abstract}
The purpose of this Community Service is to provide an understanding for the community and the government of the Hila country in collaborating on village development planning. The training and FGDs conducted by FISIP Academics at Pattimura University were aimed at increasing the capacity of the Hila state government in providing good government based on the principles of village financial governance and village development planning. The method is carried out in two stages: preparation and implementation. PKM Using a research approach namely training methods and FGD in the Village Office together with the Hila government and students. The primary data source is by conducting direct interviews with the Hila State government and the State apparatus. The conclusion of the PKM in the State of Hila is the governance of the administration of the State of Hila and saniri institutions in planning development in the Hila Village.
\end{abstract}


Caradde: Jurnal Pengabdian Kepada Masyarakat

Vol 2 No 2, Februari 2020

\section{PENDAHULUAN}

Pemberdayaan merujuk pada serangkaian tindakan yang dilakukan secara sistematis dan mencerminkan pertahapan kegiatan atau upaya mengubah masyarakat yang kurang atau belum berdaya, berkekuatan, dan berkemampuan menuju keberdayaan. Makna "memperoleh" daya, kekuatan atau kemampuan merujuk pada sumber inisiatif dalam rangka mendapatkan atau meningkatkan daya, kekuatan, atau kemampuan sehingga memiliki keberdayaan. (Nafidah \& Suryaningtyas, 2016).

Hatu (2010) dalam penelitian menguraikan bahwa pemberdayaan masyarakat sangat memperhatikan pentingnya partisipasi publik yang kuat. Dalam kaitan dengan pendampingan sosial, maka pekerja sosial seringkali diwujudkan dalam kapasitas sebagai pendamping bukan sebagai penyembuh atau pemecah masalah secara langsung. Pemberdayaan mayarakat angat membutuhkan komitemen dari berbagai elemen masyarakat termasuk para elit kekuasaan dengan mengedepankan banwa peberdayaan masyarakat merupakan tugas yang utama dari elit untuk mengurangi tingkat kemiskinan dalam masyarakat.(Hatu, 2010)

Sedangkan hasil penelitian yang dilakukan oleh La Suhu, dkk (2019) bahwa dampak dari pemberdayaan nelayan. Masyarakat mampu meningkatkan tingkat pendapatan dan memberikan kemandirian dalam mengelola potensi desa yang ada. Pemberdayaan masyarakat sanggat penting karena kelompok nelayan mendapatkan pengetahuan dan pengalaman dalam mengelola kekayaan di desa. (Bakri La Suhu, Marno Wance, Rasid Pora, Abdulah Kaunar, 2019).

Pengabdian masyarakat yang dilasanakan di Negeri Hila berorentasi pada analisis kelembagaan sistem politik yang ada di Indonesia baik infrastruktur maupun suprastruktur politik, tipologi sistem otonomi daera dan kelembagaan desa. Tujuan pengabdian masyarakat dalam bentuk FGD yaitu pertama, menjelaskan kepada masyarakat dan pemerintah desa untuk dapat memhami dinamika sistem politik di tingkat pemerintah desa. Kedua, Aktor pemerintah negeri untuk menganalisis kewenangan pemerintah desa adat dan lembaga "Saniri". Ketiga, pengabdian masyarakat yang dilakukan dapat memahami teori dalam melakukan analisis praktek dari penerapan sistem politik pada pengunan kewenangan pemerintah desa.

Praktek kuliah lapangan pada mata kuliah SPI pada substansinya adalah bagaimana membentuk serta mengetahui sebuah sistem kewenangan pemerintah desa adat yang baik berdasarkan konsep Good Governance dan undang-undang desa yang telah diberlakukan. Dari substansi tersebut maka dalam praktek kuliah mahasiswa diharapkan tidak saja memahami teori tetapi juga bagaimana mampu merumuskan dengan baik konsep konsep dari bagian bagian sistem politik yang ada di Indonesia. Kajian-kajian sistem politik Indonesia begitu dekat hubungannya dengan kewenangan pemerintah desa adat yang saat ini menjadi ciri khas otonomi desa di provinsi Maluku. Jika sebelumnya semua sistem politik Indonesia bersifat terpusat atau sentralisasi maka setelah diterapkannya Undang-Undang Nomor 06 Tahun 2014 maka diharapkan desa dapat mengatur pengeloaan dana desa (DD) serta bisa mengatur kehidupan pemerintahan desa sendiri dengan cara mengoptimalkan potensi desa yang ada. Sistem pemerintahan desa juga sebetulnya merupakan salah satu wujud penyelenggaraan pemerintahan yang efisien dan efektif. Sebab pada umumnya tidak mungkin pemerintah pusat mengurusi semua permasalahan negara yang begitu kompleks. Disisi lain, pemerintahan daerah juga sebagai training ground dan pengembangan demokrasi dalam sebuah kehidupan negara.

Dengan demikian sebuah sistem politik Indonesia baik tidak saja bertolak dari landasan hukum, akan tetapi juga harus bertolak dari kondisi objektif dalam sebuah realitas. Landasan filosofis, yuridis, politis, sosiologis, dan ekonomis hanya merupakan persoalan persoalan yamg masih abstrak, dan secara material harus mengakomodir realitas seesuai kondisi objektif. (Hasjimzoem, 2015).

PKM penyelenggaran pemerintah Negeri Hila melibatkan mahasiswa yang mempelajari matakuliah Sistem Politik Indoensia (SPI) harus memahami bagaimana sistem politik 
yang di tingkat desa yaitu tata kelola kewenangan serta penggunaan lembagalembaga kemasyrakatan secara objektif berdasarkan pada kebutuhan masyarakat dan kepentingan masyarakat desa data tersebut. Praktek SPI diharapkan mahasiswa dapat memahami teori tetapi juga praktis sistem politik yang ada pada tingkat lokal. Terkait dengan pemikiran di atas maka dalam program praktikum mata kuliah, mahasiswa semester tiga (3) Program Studi Ilmu Pemerintahan FISIP Universitas Pattimura, yang didampingi oleh para dosen pendamping melakukan praktikum dengan melakukan pengkajian terhadap isu-isu actual terkait dengan kedudukan dan kewenangan pemerintah Desa/Negeri di sejumlah Desa/Negeri di Kota Ambon dan Kabupaten Maluku Tengah.

Terkait dengan hal diatas posisi pemerintah Desa dalam konstelasinya dengan praktik desentralisasi dan otonomi daerah terlihat secara jelas setelah terbitnya UU No. 32/2004 tentang Pemerintahan Daerah. Desentralisasi menurut UU ini berhenti pada level pemerintah kabupaten/kota, dan memposisikan pemerintah Desa sebagai bagian dari pemerintah kabupaten/kota sebagaimana tersurat pada pasal 200 ayat (1) yang berbunyi antara lain "dalam pemerintahan daerah kabupaten/kota dapat dibentuk pemerintahan desa ...". sehingga Desa merupakan bagian dari pemerintahan kabupaten/kota. Dengan kata lain, pemerintah desa adalah subsistem dari pemerintah kabupaten/kota. Dalam menjalankan pemerintahannya, Desa lebih banyak menjalankan tugas pembantuan daripada menjalankan urusan desanya sendiri. Berangkat dari kehendak untuk menempatkan Desa pada posisi yang mandiri. (UU, 2014).

\section{METODE}

Metode pelaksanaan penelitian dalam pengabdian ini yaitu kami mendatangi kantor negeri Hila di Kabupaten Maluku Tengah dan memberikan FGD dengan materi tentang penyelenggaran pemerintahan negeri Hila dan tata kelola penyusunan rencana pembangunan desa.

Materi yang diberikan tentang penyelenggaraan pemerintah negeri untuk memberikan konfirmasi kepada perangkat negeri Hila untuk menjalankan tugas dan kewenangan sesuai dengan norma yang di atur dalam ketentuan Undang-Undang Desa. Pelatihan kedua tentang perencanaan pembangunan pemerintah desa dilakukan kepada perangkat desa dan pemerintah Negeri Hila untuk memahami tata kelola pembangunan yang baik dan efektif dalam perencanaan di tingkat negeri/desa.

Pengabdian masyarakat di Negeri Hila menggunakan pendekatan pengabdilan data yaitu pengunaan data primer yang di ambil dari dokumen APBdesa, dokumen perencanaan desa serta melakukan pengamatan langsung di Negeri Hila. Peneliti juga melakukan wawancara langsung dengan pemerintah Negeri Hila untuk melakukan analisis secara mendalam tentang tata kelola keuangan, partisipasi politik.

Metode pada PKM menggunakan Metode kualitatif sebagai prosedur penelitian yang menghasilkan data deskriptif berupa kata-kata tertulis atau lisan dari orang-orang dan perilaku yang dapat di amati dilapangan. (Moleong, 2007). Sedangkan tekhnik pengumpulan data yang lain, yakni menggunakan studi kepustakaan. Menurut Nasution dalam bukunya "Metode Research" mengemukakan bahwa yang dimaksud dengan studi kepustakaan adalah tekhnik pengumpulan data dengan mengadakan studi penelaahan terhadap buku buku, literatur-literatur, catatan-catatan, dan laporan-laporan yang ada hubunganya dengan masalah yang akan dipecahkan atau diteliti. Adapun tahapan PKM yang digunakan terdiri dari dua tahapan yaitu:

\section{Tahapan Persiapan}

Pada tahapan ini Mahasiswa dan dosen melakukan beberapa kegiatan meliputi: 1) Observasi awal ke lokasi pengabdian untuk memberikan konfirmasi awal kepala pemerintah desa dan masyarakat tentang konsep PKM yang akan dilaksanakan. Selain itu, survei awal untuk dapat melihat keadaan masyarakat yang ada di Negeri Hila dan meminta izin kesedian untuk melaksanakan pengabdian. Kemudian melakukan tinjauan langsung ke kelurahan untuk mengamati lokasi tempat kegiatan. 2) Peneliti melakukan kordinasi 
Caradde: Jurnal Pengabdian Kepada Masyarakat

Vol 2 No 2, Februari 2020

dengan pemerintaha negeri untuk menyepakati waktu pengabdain masyarakat.

Tahapan pelaksanaan

Menyiapkan bahan persentase materi oleh narasumber yaitu Muhtar, S.Sos.,MA selaku peneliti yang memiliki kemampuan keilmuan tentang pemerintah desa yang akan menyampaikan materi tentang penyelenggaraan pemerintah negeri. Setelah mahasiswa sampai dilokasi pengabdian sudah disediakan tempak pengabdian yaitu di Kantor Pemerintahan Negeri Hila, Kabupaten Maluku Tengah, Wawancara dengan perangkat desa, survei potensi yang ada, tata kelola pemerintahan Negeri Hila.

\section{HASIL DAN PEMBAHASAN}

Di Indonesia dapat ditemui banyak sekali kesatuan masyarakat dengan peristilahannya masing-masing seperti Dusun dan Marga bagi masyarakat Sumatera Selatan, Dati di Maluku, Nagari di Minang, atau Wanua di Minahasa. Pada daerah lain, pada masyarakat setingkat desa juga memiliki berbagai istilah dan keunikan sendiri baik mata pencaharian maupun adat istiadatnya. Pengertian tentang Desa juga dinyatakan ahli lainnya seperti Bintarto, menurut Bintarto dalam Wasistiono dan Tahir yaitu: Satu hasil dari perwujudan antara kegiatan sekelompok manusia dengan lingkungannya. Hasil dari perpaduan itu ialah suatu wujud atau penampakan di muka bumi yang ditimbulkan oleh unsur-unsur fisiografi, unsur sosial ekonomis, unsur politis dan kultural yang saling berinteraksi antar unsur tersebut dan juga dalam hubungannya dengan daerahdaerah lainnya (Sadu, Wasistiono M.Irwan, 2006).

Dari hasil penelitian tersebut terbukti masyarakat memiliki pemikiran yang sangat rasional dalam Pemilu. Dorongan uang dalam Pemilukada menjadi sesuatu yang sangat penting bagi masyarakat. Namun teori pilihan rasional Coleman dan Dawsn tidak banyak menjelaskan adanya pengaruh tingkat pendidikan dalam memengaruhi pemikiran rasional seseorang. Selain itu teori pilihan rasional Downs terlalu rumit dalam menjelaskan tentang pengaruh kehidupan ekonomi masyarakat dalam menentukan partisipasi politik. Pada intinya masyarakat akan menentukan untuk berpartisipasi ketika partisipasi tersebut memberikan keuntungan. (Subekti, 2014).

Di Maluku khususnya di pulau Ambon kekuasaan Belanda berjalan dengan tanpa menghadapi kesulitan yang begitu berarti. Hal ini disebabkan karena lingkup kekuasaan dalam masyarakat Maluku yang terpecahpecah dimana seorang raja hanya menguasai luas wilayah setingkat desa yang dikenal di Maluku dengan sebutan "Negri". (Yanuarti, S., Lan, T. J., Marieta, J. R., \& Tryatmoko, 2006). Struktur kelembagaan adat di "negri" terus eksis dan berperan secara optimal hingga mampu menciptakan keserasian dan keharmonisan dalam kehidupan sosial masyarakat Maluku. Hingga pada berkuasanya rezim Orde Baru yang secara sistematis melakukan penyeragaman sistem pemerintahan lokal sebagaimana yang ada pada masyarakat di pulau jawa. (UU, 1979).

Sejak itu posisi dan peran lembagalembaga adat yang ada di "negri" semakin melemah. Salah satu lembaga adat penting lainnya yang kehilangan perannya adalah Saniri. Sebelum undang-undang ini diberlakukan dalam melaksanakan tugastugasnya raja dibantu oleh saniri. Saniri Negeri adalah lembaga adat yang berperan mengayomi adat istiadat dan hukum adat. Saniri berperan membantu Raja atau Kepala Desa dalam menyelesaikan setiap perselisihan di lingkup negeri atau dusun. Saniri Negeri beranggotakan sekelompok orang yang terdiri dari kepala-kepala soa yakni kepala dari beberapa marga atau fam (sebutan bagi sistem kekeluargaan di Maluku yang pada umumnya berdasarkan garis keturunan ayah) yang merupakan yang telah ditentukan secara turun temurun, pemuda, keamanan yang kerap berfungsi sebagai pihak yang dimintai nasehat atau masukan dalam penyelesaian suatu kasus/sengketa. Namun seiring dengan diberlakukannya undang-undang nomor 5 tahun 1979 ini peran dari lembaga ini digantikan oleh Lembaga Musyawarah Desa (LMD), yang meskipun mendapatkan legitimasi secara umum namun tidak oleh 
masyarakat desa adat sepenuhnya, karena komposisi dari keanggotaan LMD itu yang sudah tidak lagi seperti sedia kala dimana pada waktu sebelumnya saniri beranggota kepalakepala soa yang merupakan pemimpin dari tiap-tiap marga yang ada sehingga mereka merasa terwakilkan. Perlu ditambahkan bahwa, pada saat itu peran raja dalam penyelesaian permasalahan publik, baik masalah tanah, konflik dalam keluarga, maupun masalah lainnya, hanya sebagai eksekutor dalam memutuskan suatu persoalan dan keputusan raja ini sangat ditaati oleh masyarakat, namun proses diskusi, negosiasi serta mediasi sebelum keputusan itu dibuat ada di tangan saniri, bagaimana proses komunikasi yang dibangun oleh saniri untuk mendudukan persoalan yang dihadapi oleh dua pihak yang bersengketa, bagaimana saniri menghasilkan keputusan-keputusan dalam forum komunikasi internal saniri itu untuk upaya penyelesaian permasalahan yang dihadapi, hingga bagaimana saniri melakukan pemetaan persoalan bagi persoalan yang lebih besar, jika perlu pihak mana saja perlu dilibatkan dalam penyelesaian persoalan tersebut.

Persoalannya yang dihadapi sekarang yakni, mekanisme penyelesaian masalah seperti ini oleh sebagian masyarakat sudah lama tidak dilakukan, sebagian masyarakat lebih cenderung menyelesaikan persoalan dengan bantuan pihak kepolisian, sehingga keadilan mungkin dapat diperoleh namun ketentraman dan keharmonisan serta jalinan komunikasi yang khas dalam kehidupan masyarakat negeri di Ambon akan jauh dari yang diidamkan. Apakah setelah lebih 20 tahun tidak berperan dalam penyelesaian masalah publik, lembaga adat "saniri" yang kini dihidupkan lagi mampu mengembalikan keharmonisan dan ketentraman dalam kehidupan masyarakat "negeri" di Ambon? Suatu pertanyaan pertanyaan yang tidak mudah untuk dijawab. Atas dasar inilah penulis merasa perlu untuk mengkaji tentang permasalahan tersebut melalui penelitian ini sehingga diharapkan hasilnya dapat berguna bagi masyarakat Maluku, lebih khususnya masyarakat Ambon.

PKM yang dilakukan di negeri Hila, Kabupaten Maluku Tengah untuk menjadi studi perbandingan yang menarik dalam melakukan kajian tentang model penyelenggaran pemerintah negeri serta bagaimana pengaruh partisipasi politik masyarakat desa hila yang menjalankan pemerintah secara adat setempat. Sehingga praktek pemerintah desa negeri merupakan secara sederhana dapat diartikan sebagai praktek kekuasaan untuk memilih pemimpin di negeri adat. Secara umum, pemerintahan negeri adalah proses mengarahkan proses regenerasi negeri adat tetap di jalankan sesuai dengan norma adat yang berlaku sejak lama.

PKM program studi ilmu pemerintahan FISIP Universitas Pattimura tahun 2019 di fokuskan pada Negeri Hila, Kabupaten Maluku Tengah dengan focus kajian yang berbeda sesuai dengan mata kuliah yang ikut praktek. Model praktek lapangan terdiri dari FGD, studi lapangan, dokumentasi data.

\section{Partsispasi Politik Masyarakat di Negeri}

\section{Hila}

Partisipasi politik merupakan aspek penting dalam sebuah tatanan negara demokrasi, Sekaligus merupakan ciri khas adanya modernisasi politik. Secara umum dalam masyarakat tradisional yang sifat kepemimpinan politiknya lebih ditentukan oleh segolongan elit penguasa, keterlibatan warga negara dalam ikut serta memengaruhi pengambilan keputusan, dan memengaruhi kehidupan bangsa relatif sangat kecil. Warga negara yang hanya terdiri dari masyarakat sederhana cenderung kurang diperhitungkan dalam proses-proses politik. (Sastroatmodjo, 1995). Selain itu, hasil penelitian dari Nafidah dan Suryaningtyas (2016) bahwa dalam rangka penyelenggaraan pemerintah desa disusun perencanaan pembangunan desa sebagai kesatuan dalam sistem perencanaan pembangunan daerah. Dengan adanya perencanaan pembangunan desa yang terpadu dengan system perencanaan desa diharapkan semua program yang disusun dan dilaksanakan dapat tepat sasaran. (Nafidah \& Suryaningtyas, 2016). 
Caradde: Jurnal Pengabdian Kepada Masyarakat

Vol 2 No 2, Februari 2020

Tabel 1. Partisipasi Politik Lima Negeri

\begin{tabular}{|c|c|c|c|}
\hline No & Desa/Negeri & Pemilih dan Pengguna Hak Pilih & Suara Sah dan Tidak Sah \\
\hline \multirow{3}{*}{1} & & Pemilih & 4.509 \\
\hline & Negeri Wakal & Pengguna Hak Pilih & 1.752 \\
\hline & & Partispasi & 38.9 \\
\hline \multirow{3}{*}{2} & & Pemilih & 5.731 \\
\hline & Negeri Asiluli & Pengguna Hak Pilih & 2.545 \\
\hline & & Partispasi & 44.4 \\
\hline \multirow{3}{*}{3} & & Pemilih & 6.329 \\
\hline & Negeri Hila & Pengguna Hak Pilih & 4.277 \\
\hline & & Partispasi & $67.6 \%$ \\
\hline \multirow{3}{*}{4} & & Pemilih & 5.562 \\
\hline & Negeri Hitu Lama & Pengguna Hak Pilih & 4.387 \\
\hline & & Partispasi & $78.9 \%$ \\
\hline
\end{tabular}

Sumber: KPU Kota Ambon,2019

Dari data yang diperoleh dilapangan pada saat praktek lapangan ditemukan bahwa tingkat partisipasi masyarakat negeri Hila dalam proses pemilih masih sangat baik. (KPU, 2019). Berdasarkan pada data yang KPU Provinsi Maluku tingkat partisipasi masyarakat dalam pemilihan umum masih sangat baik. Berdasarkan hasil penyampaian pada saat FGD oleh Kaur Tata Usaha dan Umum yaitu: Partisipasi masyarakat dalam pemilihan legislatif 2019 dan pemilihan gubernur dan wakil gubenur (pilgub) 2018 masih sangat bagus karena tingkat golput dan pembandingan DPT dengan yang memilih di atas $50 \%$ suara yang ikut pemilihan. Dari jumlah pemilih yang sangat sedikit sehingga tidak bisa mengantarkan anak negeri hila menjadi anggota DPRD Maluku Tengah. Namun dari 12 calon dari kecamatan leihitu hanya satu yang lolos ke Maluku Tengah dari partai Nasdem namun yang anak negeri hila yang terpilih yaitu bapak Judaidi Tupeleu, SH yang terpilih di DPRD Provinsi Maluku.(Ikram Ollong, 2019)

Terdapat lima alasan yang melatarbelakangi praktek kuliah lapangan mengambil tema tentang partisipasi politik masyarakat Negeri Hila dalam pemilihan umum. Pertama, adanya peningkatan partisipasi politik dalam Pemilukada tahun ini sebesar $67.6 \%$ bila dibandingkan dengan
Negeri Wakal yaitu sebesar 38.9\% tahun 2019. Pada Pemilukada tahun 2018 partisipasi pemilih mampu menembus angka $67.6 \%$.

Kedua, sejauh ini belum banyak ditemukan penelitian mengenai partisipasi politik masyarakat di Negeri Hila Kabupaten Maluku Tengah, Provinsi Maluku. Oleh karena itu praktek kuliah lapangan ini merupakan praktek yang dilakukan oleh mahasiswa dan dosen prodi ilmu pemerintahan untuk bisa kita jadikan bahan pembelajaran ke depan terkait analisis partisipasi politik yang sejenis. Ketiga, Tahun 2018 merupakan tahun politik bagi masyarakat Negeri Hila Kabupaten Maluku Tengah. Pada tahun 2018 masyarakat melaksanakan dua agenda Pemilukada sekaligus yakni pemilihan legislatif dan pemilihan gubernur Maluku Tahun 2018. Tentunya perhatian masyarakat pada dunia politik cukup tinggi. Situasi ini akan sangat membantu peneliti untuk melakukan praktek kuliah lapangan mengenai partisipasi politik di Negeri Hila Kabupaten Maluku Tengah.

Keempat, Negeri Hila Kabupaten Maluku Tengah dapat dijadikan contoh partisipasi politik daerah dalam wilayah Maluku. Alasan dipilihnya Negeri Hilla sebagai contoh partisipasi politik karena jika dibandingkan dengan daerah lain yang masuk ke dalam wilayah Maluku Tengah memiliki 
tingkat partisipasi yang paling tinggi. Seperti yang terlihat dalam Pemilukada Maluku Tahun 2018 lalu. Untuk Negeri Hila, Kabupaten Maluku Tengah mengungguli tingkat partisipasi pemilih.

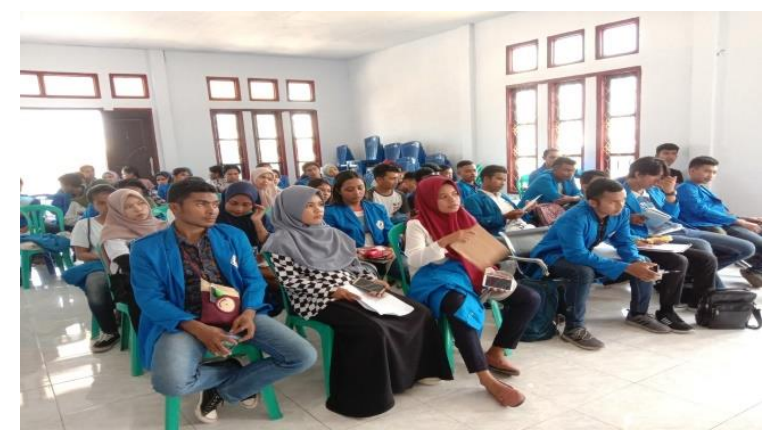

Gambar 1. Diskusi Partisipasi Politik

Sosialisasi dan pendidikan politik yang diberikan oleh lembaga sosial dalam meningkatkan partisiapsi politik ternyata tidak lantas mampu mendorong masyarakat untuk berpartispasi politik secara maksimal. Sehingga dalam hal ini praktek kuliah lapangan melihat dari sisi lain mengenai pengaruh rasionalitas pemilih dalam partisipasi politik. Terlepas dari pemahaman manusia sebagai makhluk sosial, pada dasarnya manusia merupakan makhluk individu. Makhluk invidiu memiliki tingkat rasionalitas yang sangat tinggi. Sifat dasar dari makhluk rasional adalah kalkulasi untung rugi yang menjadi dasar setiap tindakanya. Hampir semua manusia akan berusaha mendapatkan barang yang dia ingikan dengan ongkos seminimal mungkin. (Yanuarti, S., Lan, T. J., Marieta, J. R., \& Tryatmoko, 2006)

\section{FGD Penyelenggaraan Pemerintah Negeri}

\section{Hila}

Perjuangan masyarakat Maluku untuk menghidupkan kembali tatanan adat beserta kelembagaan adat yang pernah ada dalam kehidupan masyarakat Maluku merupakan suatu perjuangan yang sesungguhnya terpendam ketika berkuasanya pemerintahan orde baru. Baru setelah penetapan Undangundang nomor 32 Tahun 2004, masyarakat Maluku melakukan suatu gerakan bersama untuk menegakkan eksistensi identitas masyarakat Maluku sebagai suatu persekutuan masyarakat hukum adat yang harus diakui oleh Negara Republik Indonesia.

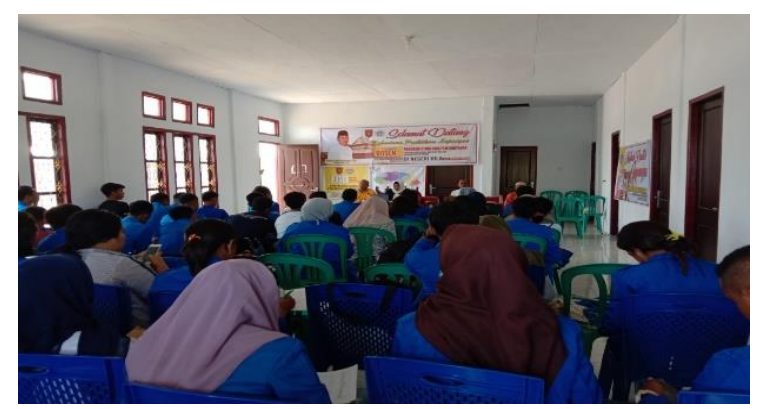

Gambar 2. FGD Lapangan Negeri Hila 2019

Oleh karena pencantuman kata 'Negeri' sebagai suatu bentuk persekutuan masyarakat hukum adat yang ada di Maluku sebagaimana telah dilakukan dalam Undangundang Nomor 32 Tahun 2004 tentang Pemerintahan Daerah sebagai koreksi dari Undang-undang Nomor 22 Tahun 1999 tentang Pemerintahan Daerah merupakan bentuk pengakuan Negara terhadap eksistensi masyarakat Maluku. Berdasarkan hasil penyampaian FGD oleh Pejabat Negeri Hilla yaitu: Sejarah berdiri Negeri Hila itu sangat tertutup. Namun bisa dijelaskan asal mula terbentuknya negeri Hila, Kabupaten Maluku Tengah. Terbentuknya negeri yaitu kedatangan empat perdana terdiri dari empat warna. Arkelogi sejarah yang bisa menjadi bukti tentang terbentuknya negeri hila yaitu jika anda berjalan di benteng Amsterdam, Hila maka akan ditemukan masjid yang menjadi empat nilai dasar. Nilai dasar menjadi pertanda lahirnya negeri yaitu mengenal perdana nestapi atau perdana jamilu, perdana toto hatu, perdana tanah hitu mesing, pati tuban atau kie pati.Mereka berempat yang pertama kali datang di negeri leihitu dan membentuk satu komunita yang orang ambon mengatan sebagai Uli atau komunitas. Uli sudah ada sejak berdiri kerajaan tanah hitu yang berdiri di atas batu kusi di tanah hitu, datang sebelum kedatang kolonialisme. Abdul Latif Anjaran, 2019)

Adapun pengakuan Negara terhadap per-sekutuan masyarakat adat yang ada di Maluku sebagaimana tercantum dalam penjelasan atas pasal 202 ayat (1) telah membuka ruang untuk bangkitnya kembali lembaga-lembaga adat yang penetapannya dilakukan berdasarkan Perda Provinsi Maluku Nomor 14 Tahun 2005 tentang Penetapan Kembali Negeri sebagai Kesatuan Masyarakat Hukum Adat Dalam Wilayah Pemerintahan 
Caradde: Jurnal Pengabdian Kepada Masyarakat

Vol 2 No 2, Februari 2020

Provinsi Maluku yang merupakan aturan turunan dari Undang-undang tersebut. Berdasarkan penyampaian Kasie Pelayanan Negeri Hila bahwa:Empat perdana berpisah yaitu satu di hitu, tiga bergerak kea rah barat yang sekarang kita kenal dengan nama daratan hila. Di anatara empat perdana di satukan dalam satu uli yaitu uli halawa atau negeri emas. Tiga di negeri di negeri hila dan satu di negeri hitu. Proses pelantikan di antara empat negeri wajib empat negeri harus hadir dalam proses pelantikan. Sedangkan kie pati atau Pati tuban diperintahkan untuk belajar di kerjaan tuban untuk belajar pemerintahan. Sehingga pati tuban balik ke negeri hitu untuk mempraktekkan system pemerintahan yang di terapkan di kerajaan tuban. Sistem pemelihan di negeri hila menerapkan system pemilihan demokrasi secara langsung.(Bapak Jabir Tatalorat, 2019).

Yang kemudian jabarkan lagi lebih detail dalam perda masing-masing daerah. Kemudian yang menjadi persoalan selanjutnya adalah bagaimana perda tersebut ditindaklanjuti hingga pada tingkat desa atau yang disebut dalam Perda Kota Ambon Nomor 3 Tahun 2008 dengan sebutan "Peraturan Negeri", dimana diharapkan dalam Perneg tersebut dapat dijabarkan lebih jauh mengenai kedudukan formal masingmasing lembaga yang ada dalam struktur pemerintahan negeri termasuk saniri yang sebelumnya hanya mendapatkan pengakuan secara sepihak oleh masyarakatnya saja sehingga pada akhirnya juga dapat diwujudkan menjadi suatu tatanan hukum yang diakui oleh negara juga secara formal.

\section{Kedudukan Bapak Raja dan Lembaga Saniri di Negeri Hila}

Desa bagi daerah Maluku, khususnya Maluku Tengah dan Pulau Ambon lazimnya disebut "Negeri", yang didalamnya termasuk Pemerintah Negeri. Dengan diberlakukannya Undang- Undang No 32 Tahun 2004, maka lembaga-lembaga adat seperti Saniri memiliki pengakuan terhadap eksistensinya yang terlegitimasi dengan nama Badan Saniri Negeri atau Badan Permusyawaratan Negeri. Meski demikian jika ditinjau dari perspektif sosial politik, ada beberapa hal yang secara fundamental cukup mempengaruhi tugas, peran dan fungsi dari Badan Saniri, misalnya tentang rekruitmen penyelenggaraan fungsi pemerintahan.

Dengan telah di berlakukannya UndangUndang No. 6 Tahun 2014 tentang Desa, maka dibutuhkan pelatihan dan pembinaan khususnya terhadap peningkatan SDM aparat desa sehingga mampu mengelola pendanaan yang telah dikeluarkan oleh pemerintah daerah kepada pemerintah desa. Hendaknya semakin ditingkatkan peran aktif warga desa dalam hal mengawasi dan mengontrol pembangunan desa. Hal ini bertujuan agar desa tidak kehilangan ciri khas desa akibat maraknya pembangunan yang telah dilakukan oleh pemerintahan desa. (Hasjimzoem, 2015).

Di Maluku Desa/Negeri dikepalai oleh seorang Raja (Kepala Pemerintahan Negeri), Raja dibantu oleh Badan Saniri Negeri. Berdasarkan Peraturan Daerah Kabupaten Maluku Tengah No. 04 tahun 2006 tentang Pedoman Penataan Badan Saniri Negeri, disebutkan bahwa: "Saniri Negeri adalah lembaga atau badan yang merupakan perwujudan demokrasi dalam penyelenggaraan Pemerintah Negeri, berfungsi sebagai badan legislatif yang bersama-sama Kepala Pemerintahan Negeri (Raja) membentuk peraturan negeri, megawasi pelaksanaan tugas dari Kepala Pemerintah Negeri serta merupakan badan yang mendampingi Kepala Pemerintahan Negeri dalam memimpin negeri, sesuai tugas dan wewenang yang dimilikinya". Badan Saniri Negeri pada saat ini tidak berfungsi optimal dalam menyalurkan aspirasi masyarakat. kondisi ini terjadi karena rendahnya tingkat kehadiran dalam setiap rapat yang di selenggarakan oleh Pemerintah Negeri, salah satu penyebabnya adalah selain kesibukan dan kepentingan pribadi, para anggota Badan Saniri Negeri juga memerlukan biaya untuk hidup mereka dan keluarganya yang sama sekali tidak terlalu banyak mengharapkan dan menggantungkan diri dari uang kehormatan atau honor sebagai anggota Badan Saniri Negeri yang belum tentu ada anggarannya.

Tingkat kehadiran anggota Badan Saniri Negeri yang rendah dalam setiap rapat menyebabkan penyusunan program kerja Negeri yang tidak responsif sesuai dengan keinginan dan aspirasi masyarakat. Lemahnya pengawasan terhadap sumber- sumber pendapatan asli Negeri dan kurangnya kepedulian anggota Saniri Negeri dalam 
Marno Wance1 Muhtar², Pahrul Idham Kaliky³. PKM Penyelenggaraan Pemerintahan

pelestarian dan pemeliharaan adat istiadat seperti Badan Saniri Negeri kehilangan fungsinya sebagai "Saniri Kewang" yang berwenang mengadili pelanggaranpelanggaran terhadap "Sasi". Apabila tidak mendapat pengawasan oleh Badan Saniri Negeri maka terjadi kerawanan sosial seperti pencurian dan pengrusakan terhadap sumber daya alam yang ada di Negeri.

Sebagian masyarakat juga menilai bahwa Badan Saniri yang terbentuk selama ini bukan murni melalui suatu meknisme adat tetapi merupakan penunjukan terhadap orangorang terdekat dengan bapak Raja (Kepala Pemerintah Negeri), anggota Badan Saniri Negeri juga dinilai tidak konsisten terhadap setiap peraturan atau kebijakan yang telah dihasilkannya. Mengakibatkan banyak Peraturan Negeri yang dianggap tidak berjalan. Adanya ketidakpercayaan antara anggota satu dengan yang lainnya sehingga menyebabkan pelaksanaan lembaga adat yang dikuasakan sebagai pengelola sumber daya alam dan ekonomi masyarakat. Adat istiadat untuk melindungi sumber daya alam serta hasil hutan dan kebun yang biasanya dilakukan beberapa larangan untuk memanen hasil tanaman tersebut sampai sampai batas waktu yang telah ditentuan oleh kewang sebagai penanggung jawab sumber daya alam Negeri. fungsi Badan Saniri Negeri tidak berjalan maksimal.

\section{UCAPAN TERIMA KASIH}

Ucapan terima kasih sebesar-besarnya kepada Fakultas Ilmu Sosial dan Ilmu Politik Universitas Pattimura, yang telah memberikan pendanaan pengabdian masyarakat tahun 2019 sehingga kami dapat melaksanakan pengbadian di Negeri Hila. Para dosen Prodi Ilmu Pemerintahan yang telah memberikan fasilitas serta jalan selama penelitian berlangsung.

\section{SIMPULAN DAN SARAN}

Berdasarkan pada hasil analisis praktek kuliah lapangan di Negeri Hila, Kabupaten Maluku Tengah maka disimpulkan: (1) Tingkat partisipasi masyarakat di negeri Hila sangat baik dalam ikut berpartisipasi dalam proses pemilihan umum. Data yang di dapat dilapangan menunjukan tingkat partisipasi politik masyarakat negeri hila sebesar $67.2 \%$ atau hampir semua menentukan pilihan pada pilkada Maluku. Data tersebut diperkuat dengan hasil wawancara untuk mengukut tingkat partisipasi masyarakat pada pemilihan legislatif maupun pemilihan presiden 2019 masih sangat tinggi; (2) Sejarah terbentuknya Negeri Hila dalam menerapkann system pemerintahan yang baik dalam melakukan tata kelola kerajaan dengan mengutus pati Tuban untuk belajar sistem pemerintahan pada kerajaan Tuban. Utusan Pati Tuban untuk belajar sistem pemerintahan dengan tujuan jika kembali ke Negeri Leihitu bisa diterapkan. Penerapan system kerajaan atau kepala pemerintah di pimpin oleh Bapak Raja sudah terjadi sejak masa lampu dan tetap dilestarikan sebagai model pemerintahan di tingkat desa. Sedangkan lembaga BPD sebagai lembaga mitra perencanaan pemerintah desa serta lembaga yang mempunya fungsi pengawasan di sebut sebagai lembaga "Saniri" Negeri yang mempunyai tugas untuk menjaga nilai-nilai adat tetap dijaga dan dipertahankan dalam menjalankan pemerintahan desa di Negeri Hila, Kabupaten Maluku Tengah; (3) Masyarakat Negeri Hila dapat menilai bahwa Badan Saniri yang terbentuk selama ini bukan murni melalui suatu meknisme adat tetapi merupakan penunjukan terhadap orang-orang terdekat dengan bapak Raja (Kepala Pemerintah Negeri), anggota Badan Saniri Negeri juga dinilai tidak konsisten terhadap setiap peraturan atau kebijakan yang telah dihasilkannya. Mengakibatkan banyak Peraturan Negeri yang dianggap tidak berjalan. Adanya ketidakpercayaan antara anggota satu dengan yang lainnya sehingga menyebabkan pelaksanaan lembaga adat yang dikuasakan sebagai pengelola sumber daya alam dan ekonomi masyarakat.

\section{DAFTAR RUJUKAN}

Bakri La Suhu, Marno Wance,Rasid Pora, Abdulah Kaunar, S. D. (2019). Intervensi Swasta Dalam Pemberdayaan Masyarakat Nelayan Di Desa Madapolo Kabupaten Halmahera Selatan( Study atCentral Madaopolo Village , North Obi District ). Jurnal Tta Sejuta STIA Mataram, 5(2), 15.

Abdul Latif Anjaran. (2019). Pejabat Kepala Negeri Hila. 
Ikram Ollong, S. P. (2019). Kaur Tata Usaha dan Umum.

Jabir Tatalorat, S. S. (2019). Kasie Pelayanan Negeri Hila.

Hasjimzoem, Y. (2015). Dinamika Hukum Pemerintahan Desa. Fiat Justisia, 8(3), 463-476.

https://doi.org/10.25041/fiatjustisia. v8no3.312

Hatu, R. A. (2010). PEMBERDAYAAN DAN PENDAMPINGAN SOSIAL DALAM MASYARAKAT (Suatu Kajian Teortis). Inovasi, 7(4), 240-254. http://download.portalgaruda.org/art icle.php?article $=40750 \& \mathrm{val}=3590 \&$ titl $\mathrm{e}=$ PEMBERDAYAAN DAN PENDAMPINGAN SOSIAL DALAM MASYARAKAT (Suatu Kajian Teortis)

KPU. (2019). Data KPU Kota Ambon. https://infopemilu.kpu.go.id/pilkada 2018/hasil/rekap/t1/maluku/maluku _tengah/leihitu

Moleong, L. J. (2007). Metodelogi Penelitian Kualitatif. PT. Remaja Rosdakarya.

Nafidah, L. N., \& Suryaningtyas, M. (2016). Akuntabilitas Pengelolaan Alokasi Dana Desa Dalam Upaya
Meningkatkan Pembangunan Dan Pemberdayaan Masyarakat. BISNIS : Jurnal Bisnis Dan Manajemen Islam, 3(1), 214.

https://doi.org/10.21043/bisnis.v3i1. 1480

Sadu, Wasistiono M.Irwan, T. (2006). Prospek Pengembangan Desa. Fokusmedia.

Sastroatmodjo, S. (1995). Perilaku Politik. Semarang: Ikip Semarang Press.

Subekti, T. (2014). Partisipasi Politik Masyarakat Dalam Pemilihan Umum (studi Trun of Voter dalam Pemilihan Umum Kepala Daerah Kabupaten Magetan Tahun 2013). $1-16$.

http://www.unpad.ac.id/2014/03/ti ngkat-partisipasi-masyarakat-dalampemilu-terus-menurun/

UU. (1979). Undang-Undang Nomor 5 tahun 1979 tentang Pemerintahan Desa.

UU. (2014). UU No. 6 Tahun 2014 tentang Desa.

Yanuarti, S., Lan, T. J., Marieta, J. R., \& Tryatmoko, M. W. (2006). Kelembagaan Pemerintah Lokal. LIPI. 